\title{
SPINOZA'S ETHICS: FREEDOM AND DETERMINISM
}

by Alfredo Lucero-Montaño

1. What remains alive of a philosopher's thought are the realities that concern him, the problems that he addresses, as well as the questions that he poses. The breath and depth of a philosopher's thought is what continues to excite and incite today. However, his answers are limited to his time and circumstances, and these are subject to the historical evolution of thought, yet his principal commitments are based on the problems and questions with which he is concerned. And this is what resounds of a philosopher's thought, which we can theoretically and practically adopt and adapt.

Spinoza is immersed in a time of reforms, and he is a revolutionary and a reformer himself. The reforming trend in modern philosophy is expressed in an eminent way by Descartes' philosophy. Descartes, the great restorer of science and metaphysics, had left unfinished the task of a new foundation of ethics. Spinoza was thus faced with this enterprise. But he couldn't carry it out without the conviction of the importance of the ethical problems or that ethics is involved in a fundamental aspect of existence: the moral destiny of man.

Spinoza's Ethics[1] is based on a theory of man or, more precisely, on an ontology of man. Ethics is, for him, ontology. He does not approach the problems of morality — the nature of good and evil, why and wherefore of human life — if it is not on the basis of a conception of man's being-in-itself, to wit, that the moral existence of man can only be explained by its own condition. For Spinoza, to work up an ethics is not to elaborate an external theory of morality, but to go deep into the intrinsic, radical, and essential constitution of the human condition:

It is impossible for a man not to be part of Nature and not to undergo changes other than those which can be understood solely through his own nature and of which he is the adequate cause (E4p4).[2]

Spinoza's commitment is essential for his search of mankind's reason. His ethics is an attempt to give reason to the human facts that usually are not susceptible to a rational explanation, and are condemned to pure irrationality. Particularly the moral facts - what Spinoza abridges as "the emotions and actions of men" — have been considered as a realm of 
existence that eludes any understanding. So the essence of our existence was conceived as an unreachable and unexplainable twilight zone, in which science and reason cannot have access. Man can explain everything, know everything and dominate everything, but himself. His own actions, the essential of his being, were marginalized, were put outside of his reach. Thus the specifically human would be a universe determined by a power external to man and alienated from his understanding.

Despite modern rationalism's dubious commitment to rationalize the whole of existence, it seems certain that Spinoza's project to make intelligible the moral world, and give it an immanent basis, is a project that grants his thought a permanent significance.[]]

2. The fundamental aim of Spinoza's Ethics is to naturalize and rationalize human life, in opposition to the philosophical tradition that looked at the realm of "the emotions and actions of men" as something extra-natura or anti-natura, alien or opposite, to a rational understanding. In this sense, Spinoza writes in a notable passage:

Most of those who have written about the emotions (affectibus) and human conduct seem to be dealing not with natural phenomena that follow the common laws of Nature but with phenomena outside Nature. They appear to go so far to conceive man in Nature as a kingdom within a kingdom... They will doubtless find it surprising that I should attempt to treat of faults and follies of mankind in the geometric manner, and that I should propose to bring logical reasoning to bear on what they proclaim is opposed to reason, and is vain, absurd and horrifying...I shall [therefore] consider human actions and appetites just as if it were an investigation into lines, planes, or bodies (E3pref).

Spinoza does not only think, in accordance with his time, that nature is written in numbers and it has in itself a casual and mathematical rationality, but that everything can be "demonstrated in geometrical order," including ethics itself.

For Spinoza, and likewise modern rationalism, nature losses its demonic character, and acquires even a divine status: In his pantheistic conception, "God is one," there is only one substance, an absolutely infinite being, consisting of infinite attributes of which only thought (spirituality) and extension (spatiality, corporeity) are known by man. God is not just thought, as Descartes believed, but also extension as the Spinozist heretical theology states. This means that 
the divine is in the physical nature as it is in thought itself. Furthermore, nature is divine itself. Everything is God, and God is everything.

If extension and thought have been unified in this basic premise, if monism tries to resolve, in an essential unity, the dualism between spirit and matter, infinite and finite, absolute and relative, eternity and temporality, we must understand that man, with all his affects, cannot constitute a sui generis reality outside of nature. If God itself is not extra-natura, even less can man be: He does not constitute "a kingdom within a kingdom."

But Spinoza's naturalism takes with itself — together with the possibility of dealing with the human affects as if they were "lines, planes, or bodies" — the possibility that freedom could be questioned:

Men are deceived in thinking themselves free (E2p35schol).

In the mind there is no absolute, or free, will. The mind is determined to this or that volition by a cause, which is likewise determined by another cause, and this again by another, and so ad infinitum (E2p48).

Here freedom seems to have no place in an absolute and necessary order, or when Spinoza writes: "that all things in Nature proceed from an eternal necessity and with supreme perfection" (E1app).

Certainly there is no freedom, if we understand by it the power of doing an action without cause or reason, if we conceived free action as the human possibility to act independently of determining causes. That would be freedom conceived as self-determination, as causa sui, for instance, as in Kant or Sartre. Here we must point out that Sartre's idea of freedom certainly takes place as the exact counterpart of the Spinozist notion: freedom is an absolute indetermination, a "complete and unconditioned" freedom — anti-natural, unjustifiable and absurd. Sartre's existentialism not only asserts the irreducibility of human condition, but it precisely assumes the extra-natura character, opposed to reason, of the "vain, absurd and horrifying" absolute freedom. And far away from the Spinozist notion, Kant's idea of freedom is outside of nature, outside of natural causality, and nevertheless it is rational (and it is a nonnatural "cause"), because it belongs to the order of practical reason. 
On the other hand, in Spinoza's rationalism takes place the most strict identity between "cause," "reason" and "nature," in which cause is the same thing as reason, reason is the same thing as cause, and cause is the same thing as a necessary causality or determinism: "From a given determinate cause there necessarily follows an effect" (E1ax3).

In other words, this determinism means that the same causes produce the same effects through a chain of uniform, determined and necessary items. It consequently makes freedom incompatible with rationality, and with nature and its causal realm. Now we can clearly understand that to assert, as Spinoza does, the rational and natural condition of human life implies the questioning of freedom.

Can we really explain what man is within a strict monist and deterministic philosophy? Can we talk about ethics in a universe ruled by necessary causal laws? Is it not a contradictio in terminis to speak about a "deterministic" ethics? How can we explain within a perfect order the universal presence of human imperfection, like man's irrationality, destructiveness and evil? Can it be an ethics "demonstrated in geometrical order"? Could Spinoza really achieve his project of a strictly deterministic ethics that eliminated all sense of freedom?

Spinoza's Ethics precisely oscillates between these alternatives: if there is ethics, there is no absolute determinism, or vice versa. If the former, then the determination is reduced, and it is not anymore incompatible with freedom; the causality ceases to be absolutely necessary (implied in a consequent determinism). If the latter, the emphasis put on a strict determinism - as a guarantee of rational perfection and absolute truth — ethics becomes impossible; it disappears in a straightforward manner to the consolidation of determinism. These two possibilities seem to be present at the same time in Spinoza's ethics, creating tensions and contradictions within his system. Nevertheless, there is an ethics, and this means that there is a mode of determinism combined with freedom. The Spinozist ethics, explicitly or implicitly, establishes several meanings of freedom. 
3. Certainly, Spinoza writes of "good" and "bad" affects: pleasure, love, devotion, hope, confidence, etc., are good affects; pain, hatred, mockery, fear, despair, are bad affects. For Spinoza, affects are rationales as much as they express man's belonging to nature, that is, his inclusion in an universal causal order by which he is necessarily affected. However, the affects can favor or not favor man's being:

I shall understand by pleasure 'the passive transition of the mind to a state of greater perfection,' and by pain 'the passive transition of the mind to state of less perfection' (E3p11schol).

However, what is fundamental in Spinoza's gaze is that man has an originating tendency, a kind of elan vital, an effort or essential impulse to persist in his own being:

The conatus with which each thing endeavors to persist in its own being is nothing but the actual essence of the thing itself (E2p7).

Desire is the very essence of man; that is, the conatus whereby man endeavors to persist in his own being (E4p18dem).

In contrast with those that might see in the human condition some originating tendency to destruction or death, like Freud who asserts that "the aim of all life is death" or Heidegger who understands human existence (Dasein) as a "being-toward-death," Spinoza holds that death is external or extrinsic: "No thing can be destroyed except by an external cause" (E3p4).

For Spinoza, the good affects are those that favor the originating conatus of life, toward its expansion and perfection, that is, to joy and happiness. The bad affects, on the contrary, disturb the being's impetus:

Pleasure is an emotion whereby the...[man's] power of activity is increased or assisted. Pain, on the other hand, is an emotion whereby the...[man's] power of activity is diminished or checked. Therefore pleasure in itself is good...[and pain is in itself bad] (E4p41dem).

I shall mean by 'good' that which we certainly know to be the means for our approaching nearer to the model of human nature that we set before ourselves, and by 'bad' that which we certainly know prevents us from reproducing the said model (E4pref).

Here it is necessary to notice that the existence alone of the "bad" affects could be a sign of a break in the supposed human perfection;[4] if not, how can we really understand 
melancholy, grief, fear, hatred, death, in a realm where everything "endeavors to persist in its own being," and in a realm that is subject to the most necessary and divine rationality?

The fact alone of the existence of a difference, or contrast, between good and bad affects is a proof - grounded on freedom — of the ethical condition of man. For a strictly deterministic system there is no place for qualitative distinctions: everything is indifferent, apathetic, neutral, because everything is precisely necessary. The difference between good and bad affects implies the negation of the perfect causal order, or it reveals the existence of an imperfection, and therefore the possible character of determination. The diversity implies then the different alternatives of possible, unlike and opposite, causal links: some favorable to man's essential nature and others opposite to it, some of life and others of death. It seems that we live in a world determined by a kind of necessity-in-the-circumstances (relative necessity), and not one of absolute necessity: what is, but could not be; what is this way, but could be in another way. And this notion of necessity-in-the-circumstances is related to freedom.

On the other hand, the difference does not only exist, according to Spinoza, between good and bad affects, but between emotions in general and actions; between the passive life which is affected by the exterior,[]] and the active life which, on the contrary, is a cause itself, and not only an effect. The "power of activity" that moves human nature "by reason of its essence or by reason of its cause," and produces its own motion — from inside to outside, and not from outside to inside - means nothing else but the fulfillment of the conatus itself:

Besides the pleasure and desire that are passive emotions, there are other emotions of pleasure and desire that are related to us in so far as we are active (E3p58).

Since reason demands nothing contrary to nature, it therefore demands that every man should love himself, should seek his own advantage (I mean his real advantage), should aim at whatever really leads a man towards greater perfection, and, to sum it all up, that each man, as far as in him lies, should endeavor to preserve his own being (E4p18schol).

For that reason, melancholy, hatred, sadness (passive affects), are not actions (active affects), and for the same reason, the actions agree with the good affects:

So no emotions of pain can be related to the mind in so far as it is active, but only emotions of pleasure and desire (E3p59dem). 
Certainly, the difference between passive and active affects, between passivity and activity, shows the "human weakness in the ethical struggle,"[] or in Spinoza's words, it shows the essential difference between bondage and freedom:

We shall readily see the difference between the man who is guided only by emotion and belief and the man who is guided by reason. The former, whether he will or not, performs actions of which he is completely ignorant. The latter does no one's will but his own, and does only what he knows to be of greatest importance in life, which he therefore desires above all. So I call the former a slave and the latter a free man (E4p66schol).

A free man thinks of death least of all things, and his wisdom is a meditation of life, not of death (E4p67).

For Spinoza, real freedom would not consist hence in acting gratuitously, without cause nor reason, but on the contrary to act according with the necessary nature of man:

To act from reason is nothing else but to do what follows from the necessity of our own nature considered solely in itself (E4p59dem).

It is in the nature of reason to regard things as necessary, [to wit, as they are in themselves] (E2p44cor2dem).

In other words, for Spinoza, freedom means to obey the determined conatus which man "endeavors to persist in its own being," acting in agreement with "the clear and distinct ideas" which show the universal rationality, and in conformity with the necessary and eternal truths of nature. Thus freedom would be nothing but the fulfillment of the own necessity of being:

The conatus to preserve itself is nothing but the essence of a thing, which... is conceived as having a force to persist in existing and to do those things that necessarily follow from its given nature. But the essence of reason is nothing other than our mind in so far as it clearly and distinctly understands (E4p26dem).

In this sense, we might say that the change between the passive life and the "free" and active life is nothing but the change of one bondage to another one: to leave acting from external causes (passive affects) and to subject oneself to internal determinations (active affects) which are absolutely more determining. Then freedom would be just the outcome of a fixed, determined and immutable nature, an absolute, necessary nature, and not a possibility itself. Spinoza does not admit that "free" action can fall on our own nature and transform it, that is, freedom cannot be creative and produce true changes; therefore it could not explain the ethical condition of man. 
However, in another sense, we cannot think that "active" life and "passive" life are indifferent, nor that the change of one to another does not, in some way, imply freedom. It, explicitly or implicitly, shows the condition of the ethical activity (man's active understanding of himself), even though it is conceived in a limited way and it fulfills in conformity with a supposed nature, or a necessary essence.

We could even say that the paradox is double: for it not only expresses that freedom consists in necessity, but that necessity involves, at the same time, freedom; man's necessary nature (his rational conatus to persist in his own being) is not absolutely necessary: it does not inevitably come to fulfilment in a spontaneous and automatic manner, as a natural instinct. On the contrary, it is a free acquisition, possible and contingent, borne in the effective man's activity, through which could it take place or not. Certainly, the conatus is just "conatus" in the sense as "tendency", possibility or potentiality, "endeavor," struggle and conquest of freedom. It properly is not a force, or a spontaneous impetus, which takes place with natural and universal facility. Spinoza seems to acknowledge this when he writes: "If men were born free, they would form no conception of good and evil so long as they were free" (E4p68).

Actually, for man, the conatus is a potency, a "desire", an "endeavor," which requires human "work", to wit, requires art (activity) and artifice (virtue); it is a cultural outcome and not a natural one; it is moral and free, not spontaneous nor absolutely determined. However, for Spinoza, the real active and free life is something very difficult to reach:

If the road I have pointed out as leading to this goal seems very difficult, yet it can be found. Indeed, what is so rarely discovered is bound to be hard. For if salvation were ready to hand and could be discovered without great toil, how could it be that it is almost universally neglected? All things excellent are as difficult as they are rare (E5p42schol).

Beyond this explicit acknowledgment, freedom is present in the Spinozist system showing, in many ways, the inconsistency of determinism. Man can and must ruled over his passive affects; he must arise above the vital determinism and produce an active and rational life:

Therefore the more we endeavor to live by the guidance of reason, the more we endeavor to be independent of hope, to free ourselves from fear, and to command fortune as far as we can, and to direct our actions by the sure counsel of reason (E4p47schol). 
All the Spinozist actions ("conatus," "desire," "virtue", "power") do not mean anything else but freedom - the human power to influence over the causal chains, and thus transform human nature. It is true that freedom is not absolute or uncaused, and neither anti-natura nor extra-natura, but it also means that man's nature is not a closed, immutable, causal realm. That is why we have history, culture and ethics.

4. Beyond the effort of Spinoza's thought to apprehend the real, beyond his rationalistic commitment, the facts themselves, with their qualitative diversity and "motion and rest," overflow the Spinozist system. In effect, the fluidity of human activity exceeds the rigid and limited margins of Spinoza's determinist scheme within which he tries to rationalize ethics. It is only possible in an unnecessary, changing, imperfect order, to wit, in a human not divine order. Ethics is only possible as the world recovers its human dimension: imperfect and perfectible, essentially qualitative, always subject to siege by irrationality and nothingness, always open and in gestation. In a geometrical order there is no ethics: there are no passive and active affects, there is no difference, there is neither conflict nor struggle, neither life nor possibility.

Certainly, there is no ethics in pure indetermination, nonsense and vacuousness. The human world is an ethical world because within it there is also causality, rationality, differentiation, sense and "conatus to preserve the nature of the thing itself." Spinoza's actuality is not due to his determinist rationalism, but to his endeavor to seek the logos of the human affects, and to understand the paradox of freedom intrinsically, but not contradictorily, related to determination. It is not due to his monism or pantheism, but to his recovery of human nature and its own affects. Nor is it due to his univocal optimism, but to his advocate for vital values. In sum, it is in his effort to conciliate the passions and actions, that is, the natural and moral horizons of human life.

On the most extreme antithesis of Hobbes' statement: homo hominis lupus, we can find the Spinozist deification of nature and man himself. But opposite to Spinoza's implicit homo hominis deus, contemporary ethics stands on the fruitful hope that neither lupus nor deus, but homo hominis homo.[7] In this sense, Spinoza is a fundamental contribution to an ethics based on the human condition itself. 
Finally, there is no ethics without freedom. Even in Spinoza's deterministic conception there is an "ethics" in the broad sense. Because an indifferent and apathetic universe (consequent of an absolute determinism) is not a "human world", therefore, freedom is present. Freedom means the capacity of "option," "value" judgment and "decision," because there are, one way or another, open alternatives and possibilities. The ethical reality is the work of man's "endeavor".

\section{Footnotes}

1. Benedictus de Spinoza, Ethics, trans. Samuel Shirley (Indianapolis: Hackett, 1991).

2. References to Spinoza are given by the internal form, for example, 'E' stands for Ethica (followed by the number of the part), and so the following terms: p(roposition), dem(onstration), schol(ilum), ax(iom), app(endix), cor(ollary), pref(ace), etc.

3. Henceforth I heavily draw on Juliana González, "El Proyecto de una Ética Determinista: Spinoza," in Ética y Libertad (México: UNAM, 1989), 97-110.

4. Just a simple a question: Is not perfection inhuman?

5. For Spinoza, man as part of Nature could be assailed by external causes, and the passions resulting from them (E4ax, E4p5).

6. See Herman De Dijn, "Spinoza's Ethics: From the Sorrows of Reason to Freedom and Beyond," in La Ética de Spinoza. Fundamentos y significado, Actas del Congreso Internacional: Almagro, 24-26 de octubre, 1990 (Ciudad Real: Ediciones de la Universidad de Castilla-La Mancha, 1992), 495.

7. See Fernando Savater, Invitación a la Ética (Barcelona: Anagrama, 1982), 38.

Alfredo Lucero-Montaño (Tijuana, México) holds a master's degree in philosophy from San Diego State University (San Diego) and a bachelors in philosophy from Universidad Iberoamericana (México City). 